This paper was written by Janet Ulph, AHRC Fellow, School of Law, University of Leicester. It was accepted by the International Journal of Cultural Property (2015) 22 177-204. It does not include editorial input by Cambridge University Press.

\title{
Dealing with UK Museum Collections: Law, Ethics and the Public/Private Divide
}

\section{INTRODUCTION}

When UK national museums were created from the $18^{\text {th }}$ century onwards, the intention was to take cultural objects which were in private hands, and to place them in public ownership. It was hoped that they would provide the public with an educational experience. ${ }^{1}$ The statutes which created these museums promoted the idea that, as a general rule, these works of art and antiquities would be available to the public forever and would never return to the private sphere. This notion that museums would retain and care for objects in perpetuity was embraced by the public, who were often keen to give their works of art, curios and other cultural material not only to the national museums but also to the smaller regional museums which were created in the $19^{\text {th }}$ and $20^{\text {th }}$ centuries. Large collections were amassed by museums, as cultural objects were transferred from private individuals to public bodies.

Yet the accumulation of works of art and other cultural objects has caused problems in the twenty first century. For example, there are objects in UK museum collections which have little educational or cultural value and which consequently offer little to interest visitors: these objects were accepted many years ago when offers of gifts were not subject to the same scrutiny as they receive today. Objects may also be unwanted because the mission of the museum has changed and they look out of place with the rest of the collections. There has therefore been a growing recognition that it is sensible to review and rationalise collections.

Storage difficulties and financial cutbacks by central and local government have also encouraged museums to consider deaccessioning and disposing of objects. For example, vast amounts of archaeological material and large objects, such as sailing vessels, may put immense strains on display areas and storage facilities and may make it impossible for a museum to accept fresh gifts of culturally important objects. Museum collections may also be very costly to preserve. ${ }^{2}$ Rationalisation of collections can mean

1 Saumarez Smith, "Museums, Artefacts and Meanings" 6.

2 This is particularly true of objects made with animal or vegetable fibres, which are vulnerable to decay due to changes in humidity and attacks by pests. For example, in 1996, the Director of the National Maritime Museum declared that it cost $£ 20,000$ per year to care for 3,000 flags in the museum's collection: C. Milner, "Greenwich Sell-off Triggers Art Row" (1996) Sunday Telegraph 29 October. 
that objects can be enjoyed elsewhere, whilst allowing resources to be reassigned to conserving other objects in the collections.

But deaccessioning and disposal of museum objects can be controversial because it goes against public expectations. It is a matter of particular concern where an object, such as an antiquity or work of art of high cultural value, is sold by auction and ends up being returned to the private sphere with the risk that it has been lost to the viewing public forever. In contrast, where a museum gives its unwanted items to other museums, there is little reason for dissent. They remain in the public sphere. Even where a mistake is made, such as where a duplicate is removed and its value to the collection is only later understood, it is still available for public viewing.

It is now generally accepted in the museum sector that it is part of good heritage management to review collections and to identify objects which are not being engaged with by the public. The Museums Association's Code of Ethics reflects this consensus by noting,

Sometimes transfer within the public domain, or another form of disposal, can improve access to, or the use, care or context of, items or collections. Responsible, curatorially motivated disposal takes place as part of a museum's long-term collections policy, in order to increase public benefit derived from museum collections. ${ }^{3}$

Thus, where an object is deaccessioned as part of a "curatorially motivated" disposal procedure, the museum is encouraged to offer it as a gift to other museums, in order to keep it in the public sphere. It is only where no museum expresses any interest in the object that it might be put up for sale.

The Code of Ethics focuses in particular upon the "public" side of museums. They must reach out to attract new visitors and to remain relevant to modern day society. They may want to loan objects from collections to other museums as part of this process of making their collections more accessible. But they also need to have good financial standing. Governing bodies are therefore obliged to take a business-like approach in attracting inward investment; this may mean, for example, considering proposals to hire out parts of the collection to commercial concerns for private events.

In adopting a more commercial approach, there has been a trend towards commodifying collections. This is not remarkable where the collection needs to be insured. But increasingly museums are required to obtain valuations in order to satisfy third parties, such as local authority auditors. The valuation of a collection may reveal that some objects are worth millions of pounds. These valuations have encouraged some members of governing bodies to see their museum's collections primarily as financial assets. As a result, there seems to be increasing tension between those who consider that all museum collections must stay in the public sphere and those who wish to raise funds through sales to the highest bidder regardless of the risk that these artefacts may disappear into a private collection.

This article explores the extent to which the law reflects the public perception that, if a cultural object is donated to a museum, it will remain in its collections forever. It considers whether commercial law thinking, which applies to dealings with any objects,

3 Code of Ethics (Museums Association, 2008), Part 6; available at http://www.museumsassociation.org/download?id=944515 
is not always well suited to serve the needs of the museum sector and whether there should be more thought given to the public nature of museums. It calls for law reform in order to ensure that UK law and ethical guidance relating to disposals from collections is sufficient to maintain public trust so that people continue to visit museums and to support them with donations.

\section{UK NATIONAL MUSEUMS AND PUBLIC TRUST}

The national museums are those which are regulated by special statutes and which receive central government funding. ${ }^{4}$ These statutes vary in their provisions according to the museum in question; there are subtle but important differences in the law to reflect the mission of each museum, its particular characteristics, and its historical development. However, the underlying basis of all of the statutes is to protect and conserve the collections and to make them accessible to the public. ${ }^{5}$

The legislation creates a special relationship between the national museums. Thus, if someone leaves a work of art when he dies as a "gift to the nation," it will be transferred to one of these museums (assuming that they are willing to accept it). ${ }^{6}$ The special connection is significant in relation to disposals. Where these museums have any power to deaccession and dispose, ${ }^{7}$ they are free to transfer objects from their collections, and related documents, to each other by way of "sale, gift or exchange." 8 This freedom appears to pose no risks to public trust because the object will remain in the public sphere.

4 The list is as follows: the British Museum, the Imperial War Museums, the National Gallery, the Royal Museums Greenwich, the National Museums Liverpool, the Science Museum Group, the National Portrait Gallery, the Natural History Museum, Royal Armouries, Sir John Soane's Museum, the Tate, Victorian and Albert Museum; the Wallace Collection; the Horniman Museum; the Geffrye Museum; The British Library, The Museum of London, The Board of Trustees of the National Galleries of Scotland; The National Library of Scotland and the Board of Trustees of the National Museums of Scotland. The following museums can receive objects from (but not give them to) the other museums: the Court of Governors of the National Library of Wales, the Council of the National Museum of Wales, the Trustees of the Ulster Museum and the Trustees of the Ulster Folk and Transport Museum.

5 See, for example, the British Museum Act 1963, sec. 3 and the Museums and Galleries Act 1992, sec. 2.

6 Museums and Galleries Act 1992, sec. 7, Sch. 5, Part 1.

7 The Wallace Collection Board cannot dispose: it has a duty to maintain the collection of objects known as the "Wallace Collection" intact; the Board therefore cannot either add or remove any items from the collection: Museums and Galleries Act 1992, sec. 4(6).

8 See, for example, the British Museum Act 1963, sec. 9; Museums and Galleries Act 1992, sec. 6. 
The position is different where there is a proposal to dispose to a recipient which is not a national museum. In this situation, there may be a complete prohibition on disposal; ${ }^{9}$ if there is a power to dispose, it will be very limited. For example, in relation to the British Museum, the British Museum Act 1963 states that the trustees can only sell, exchange, or transfer if:

"(a) the object is a duplicate of another such object, or

(b) the object appears to the Trustees to have been made not earlier than the year 1850, and substantially consists of printed matter of which a copy made by photography or a process akin to photography is held by the Trustees, or

(c) in the opinion of the Trustees the object is unfit to be retained in the collections of the Museum and can be disposed of without detriment to the interests of students." 10

This last clause, or its equivalent in the statutes governing a number of other national museums, has given curators and their governing bodies considerable freedom. It has allowed them to sell objects from their collections to private individuals which are deemed unsuitable to remain in the collections. Unfortunately, serious blunders have been made. For example, in 1949, the Victoria and Albert Museum sold some chairs at auction. It was later discovered that the chairs were of great cultural value, having been part of a set of chairs commissioned in the $18^{\text {th }}$ century by Doge Paolo Renier of Venice. ${ }^{11}$ Sadly, in the meantime, the purchaser of the chairs had turned them into stools and mirror frames. There were a number of sales between the 1950s and 1970s which followed the same pattern: sales at a low price to private buyers coupled with a later realisation that the items were far more valuable in both cultural and financial terms than was appreciated at the time.

A common thread which runs through the statutes is a concern to benefit the public; a standard provision is that, if an object is sold, the proceeds of sale must be used to purchase objects to add to the collections. ${ }^{12}$ Yet the statutes governing the national museums fail to flesh out the concept of public benefit. In particular, they offer no further guidance in relation to the process of recognising and disposing of unfit or unsuitable objects. For example, there are no provisions which warn trustees of the dangers of making rushed decisions without careful examination of the objects earmarked for disposal. This is a lacuna in the law which could be remedied by fresh legislation which spells out the trustees' duty of care in relation to collections more clearly.

The statutes governing the national museums seek to reassure the public by providing that, even where a national museum can dispose of an object, it does not override any

9 The National Gallery cannot dispose to any museum other than a national museum: Museums and Galleries Act 1992, secs. 4(3), 6.

10 British Museums Act 1963, secs. 5(1), 8(3), as amended by the Museums and Galleries Act 1992, sec. 11(2), Sch. 8, para. 1 (italics added). For the background to the drafting of sec. 5 of the 1963 Act, see Mahon, "Disposing of Disposal," 732.

11 Mahon, "Disposing of Disposal," 732; NMDC, Too much stuff? at p 13.

12 Museum and Galleries Act 1992, sec. 4(7); British Museum Act 1963, sec 5(3); National Heritage Act 1963, secs. 6(6). 
conditions imposed by benefactors making gifts to these museums. ${ }^{13}$ However, one commentator has asked if it was not

"grotesquely invidious that persons who might wish to benefit the public art collections of this country should be forced to take elaborate precautions to ensure that the assets which they would like to make over to the nation are not misused in the future by fallible government employees." ${ }^{14}$

Yet, despite any flaws and mistakes made, the laws governing the national museums appear to have fostered public confidence in the whole of the museum sector.

\section{UK CHARITIES AND PUBLIC TRUST}

For over four hundred years, it has been recognised in the UK that there are some purposes which are so vital to the well-being of the nation that they deserved support by way of charitable status; ${ }^{15}$ in modern times, the most significant benefit has been exemptions from various taxes. However, in order to obtain charitable status, the purposes of an institution must be charitable in a way recognised by law. ${ }^{16}$ The Charities Act 2011 lists a series of charitable purposes: museum will normally register as charitable if their purposes are either to advance education, or to advance the arts, culture, heritage or science. ${ }^{17} \mathrm{~A}$ further requirement is that they must act for the public benefit. ${ }^{18}$

National museums and university museums enjoy charitable status. ${ }^{19}$ The UK also has a number of independent museums, many of which are charities too. Museums which are charitable clearly have a very strong "public" element. However, it is important to appreciate that not all museums which appear to be public in nature, are in fact charitable. For example, if one of the main purposes of a museum is a private one, such as to promote the reputation and interests of a private company, it would not be charitable even though the museum is open to the public. ${ }^{20}$ This dividing line between the public and private spheres is not necessarily understood by ordinary members of the public. For example, it was generally assumed that the Wedgwood Museum's collection was permanent and inalienable and people may have donated objects to the museum's collections on that basis. ${ }^{21}$ However, the collection was not held on charitable trusts. ${ }^{22}$

13 Although there may be an exception where an object has become useless because it has been damaged or become infested with pests: see the Museums and Galleries Act 1992, sec. 4(5).

14 See Mahon, "Disposing of Disposal," 733.

15 For many years, the definition of a charity had been based upon court decisions relating to the preamble to the Charitable Uses Act 1601.

16 Williams' Trustees v Inland Revenue Commissioners [1947] A.C. 447, HL.

17 Charities Act 2011, sec. 3(b)(f).

18 Charities Act 2011, sec 4.

19 See the list of exempt charities in Charities Act 2011, Sch. 3.

20 Charities Act 2011, sec 1(1)(a).

21 The author is aware of at least one donor who had given objects to the collection on the assumption that the collection would be held for the benefit of the public forever. 
The Wedgwood company and its associated museum company became insolvent and, as the entire collection was company property, it appeared that it would need to be auctioned off to pay the substantial pension deficit liability across the whole of the Wedgwood group of companies. Fortunately, nearly $£ 16$ million was raised from various sources, including from a public appeal, to save the collection for the nation; the collection has now been gifted to the Victoria and Albert Museum, a national museum, and is finally subject to the protection of charity law. ${ }^{23}$

The Charity Commission's objectives include promoting public trust and confidence in the integrity of charities and furthering an understanding of how they can benefit the public. ${ }^{24}$ Charities are accountable to the public: the Commission has observed that, "The public has an interest in charities, in particular as beneficiaries, donors, volunteers and taxpayers." ${ }^{25}$ In order to achieve these objectives, the Commission provides reports and booklets offering guidance to the governing bodies of charities. One might consequently expect that charitable museums would receive clear directions in relation to how they should deal with their collections in order to retain the public trust.

The Charity Commissioners produced a Report entitled Museums and Art Galleries in 2002, which does provide some guidance on reviewing collections, concentrating on two concerns which would arise on acquisition or at a collections review. Firstly, the Report repeatedly emphasises that the collection must have merit. ${ }^{26}$ This principle rests on decided cases. Thus, in Re Pinion, ${ }^{27}$ the testator had stated in his Will that his studio and its contents should be kept intact as a museum. However, the Court of Appeal decided that this gift did not deserve charitable status. The court noted that experts had suggested that most of the objects, such as pictures (some of which the testator had painted), were of low quality and had no educational value. ${ }^{28}$ This insistence that objects must have cultural value does not erode public trust and does encourage the process of collections review and disposal of unsuitable objects. ${ }^{29}$

The second concern expressed in the Report was that the collections should be engaged with by the public. Museums are therefore encouraged to lend objects in order to further public engagement. ${ }^{30}$ The Report states,

"There is no objection to storage of exhibits for good reasons but there comes a point where 'storage' becomes hoarding if there is no reasonable expectation

22 See Wedgwood Museum Trust Ltd [2011] EWHC 3782, [2013] B.C.C. 281.

23 The collection has been loaned to the Wedgwood Museum to be viewed by the public: http://www.savewedgwood.org/news/loan-of-wedgwood-collection-to-barlastonsecured

24 Charities Act 2011, sec 14.

25 See Risk Framework (June, 2012) p 2, available at https://www.gov.uk/government/uploads/system/uploads/attachment_data/file/313453/ris k-framework-our-regulatory-approach-to-protecting-the-public_s-interest-in-charity.pdf

26 "Museums and Art Galleries," at paras. 7-11 and 14; Annex A.1-18 and B.15-16.

27 Re Pinion, Decd. Westminster Bank v Pinion [1965] Ch. 85, C.A.

28 [1965] Ch. 85, C.A, 106, 108. See further, Sutherland's Trustee v. Verschoyle 1967 SLT 106, Court of Session.

29 "Museums and Art Galleries," Annex A.2: "In the case of a museum not concerned with art, for example a science museum, we need to be satisfied that the collection(s) and the use made of it/them educate the visitor, or is/are capable of doing so."

30 "Museums and Art Galleries," Annex A.25. 
that they can or will be exhibited. Where a museum or art gallery runs into this sort of difficulty we would expect the trustees to consider whether their holding of such collections is for the public benefit if access to the public, or interested sections of it, is in practice negligible or non-existent." 31

The Report therefore encourages disposal of objects where there is no sound reason to retain them in the collection.

The Museums and Art Galleries Report also provides some guidance in relation to a museum's relationship with those who have supported the museum by donating objects to its collections. ${ }^{32}$ This section of the Report emphasises that the museum must act in a manner which benefits the public, so that any private benefit which the donor might receive is incidental to the main charitable purposes of the museum. For example, if a private individual lent a work of art to a museum, the Charity Commission might enquire further if it had been agreed that the museum would spend large sums of money in repairing it. This approach, which is based upon a sound rationale, can create problems for museums if they have an object which is no longer wanted by the museum (and is of no interest to other museums) but which is of special value to the donor. In normal circumstances, the donor cannot expect the return of a gift, once it has been made. Charity trustees must hold charity property for the benefit of the public. However, the position is less clear where a museum wishes to dispose of an item which is quite personal, such as medals or wedding dresses. Typically these things have little financial or cultural value but have great sentimental value to the donor. If no other museum wanted these objects, it could damage the museum's reputation to auction them to the highest bidder. A commercial approach would appear heartless and completely inappropriate.

The trustees may be able to justify returning these items to donors on the basis that this is in the best interests of the museum to do so. However, if the position seems uncertain, such as where the value of an object such as a medal is difficult to determine, charity trustees could seek permission from the Charity Commissioners to return the object in accordance with section 105 of the Charities Act 2011, where it is "expedient" to do so. In other words, it must be in the museum's best interests to take this action. The Commission is likely to authorise the return where the museum's reputation might suffer with the general public if they were to sell the items instead. The fact that it may be in a charity's best interests to suffer a financial loss to satisfy public expectations was recognised by Cross J. in Re Snowden in relation to the power under section 106 of the Act to sanction ex gratia payments of money,

"it would be odd that a charity which depends for its continued existence on the recognition by members of the public of a moral obligation to give to charity should itself be incapable of giving effect to any moral obligation however strong." 33

A museum's relationship with past donors inevitably needs to be considered in order to retain public trust. Where it appears impossible to keep unwanted objects in the public domain, it would surely be in line with public expectations to return an item to a donor who may have a special emotional attachment to it, rather than to take a strictly commercial view by selling it instead. This issue was therefore discussed when the

31 "Museums and Art Galleries," Annex A.27.

32 "Museums and Art Galleries," Annex A.38-A.41.

33 Re Snowden [1970] Ch. 700, 709. 
Museum Association's Disposal Toolkit was updated, which provides more detailed guidance to museums to supplement the Code of Ethics. ${ }^{34}$ The Disposal Toolkit met with the approval of the Ethics Committee of the Museums Association; it states that museum trustees may consider returning items of low financial and cultural value to donors. ${ }^{35}$ Although this means that a museum object would be returned to the private sphere, it is confined to quite narrow circumstances.

However, the report provides no general guidance on where objects should go on disposal. This seems to be a missed opportunity because there is guidance in the general law which could be extrapolated and applied in the context of disposal. For example, the Trustee Act 2000 requires trustees to exercise care in investing trust money, delegating tasks to agents and taking out insurance ${ }^{36}$ they are expected to take advice and review any investments which they might make. ${ }^{37}$ All trustees (including charity trustees) must act in the best interests of their charity. ${ }^{38}$ It would not be difficult to project from these principles to conclude that charitable museums should consult other museums or relevant experts, as appropriate, and reflect upon any advice received before reaching a final decision to dispose.

The Museums and Art Galleries Report provides no guidance on disposals. Unlike the guidance in the Code of Ethics, there is no suggestion in the Report that every effort must be made to keep objects in the public domain by transferring them as gifts to other museums. Even so, charity law makes it difficult to sell objects from collections to private bidders. Where objects are donated with the proviso that they be kept on display, the museum would need to seek authorisation from the Charity Commission prior to any sale. ${ }^{39}$ Even where there is no such express condition, if one of the museum's principal purposes is to display collections to the public, there will be a presumption that the object was given for this purpose and authorisation from the Charity Commission will be needed. ${ }^{40}$ It is in this context that it was observed in the Cottesloe Report that,

"When a work of art is given to a museum or gallery for general exhibition, the public thereby acquires rights in the object concerned and these rights cannot be set aside. The authorities of the museum or gallery are not the owners of such an object in the ordinary sense of the word: they are merely responsible, under the authority of the Courts, for carrying out the intentions of the donor." ${ }^{41}$

34 Available at http://www.artscouncil.org.uk/media/uploads/pdf/Disposal Toolkit.pdf. The author worked as part of a team on updating the Disposal Toolkit and preparing guidelines on financial motivated sales along with Caitlin Griffiths, an independent museum consultant, Maurice Davies from the Museums Association, and Samuel Rowlands from Arts Council England. Isabel Wilson from Arts Council England managed the project.

35 Disposal Toolkit, p 17.

36 Trustee Act 2000, sec. 1, Sch 1.

37 Trustee Act 2000 , sec. 5 .

38 This is one aspect of a trustee's fiduciary duties which s/he owes to the trust: $A / B$ Group (UK) plc v Mark Redler \& Co [2014] UKSC 58, [2014] 3 WLR 1367, SC, at [83].

39 Charities Act 2011, sec. 105. A cy-près scheme would need to be drawn up if the charity's purposes needed to be modified in some way: Charities Act 1911, sec.

62(1)(e)(iii).

${ }^{40}$ Report into the Sale of Works of Art by Public Bodies, at para. 31.

41 Report into the Sale of Works of Art by Public Bodies, at para. 30. 
It is therefore only where the charitable museum holds the object as part of its general resources that charity law will not impose special restrictions on sale. But, even in this situation, a sale would need to be demonstrated to be in the museum's best interests or the Charity Commission might intervene. Any proceeds of sale (or object purchased with the proceeds) would be held for charitable purposes. Furthermore, checks would always need to be made to ensure that sales were not prohibited by a governing statute or instrument; for example, a university museum will not able to sell if the university's statute does not permit it. ${ }^{42}$ In summary, although guidance issued by the Charity Commission is deficient in failing to fully explore how museums may work to serve the public interest, charity law does restrain reckless dealings and helps to promote public trust.

\section{LOCAL AUTHORITY MUSEUMS AND PUBLIC TRUST}

Local authorities play a major role in delivering public services, such as education and housing, at a local level across England and Wales. They are "public" bodies in the sense that they receive public money from local taxation and charges and grants from central government. The councillors who run local authorities are directly elected by the local community which they serve. Local authorities are largely under the control of central government because they derive their powers and duties from statute; even so, they do have some discretion in relation to how they exercise their powers and how the public money which they receive is spent. ${ }^{43}$ For example, section 2 of the Local Government Act 2000 empowers local authorities to do anything which they consider is likely to achieve the promotion or improvement of the economic, social or environmental well-being of the local area.

Local authority museums are a significant part of the museum sector. In a 1991 Report, the Audit Commission calculated that they attracted about 20 million visitors each year. The Commission observed that.

"Local authority museums differ considerably in size and in the themes they cover, ranging from great nineteenth century municipal foundations to smaller institutions which concentrate on their local area; over $40 \%$ have been set up in the last two decades." 44

The Museums of Art Act of $1845^{45}$ encouraged the establishment of museums in large towns. It declared that ownership of the museum collections would be vested in the Mayor, Aldermen and Burgesses of the Borough and that the collections would be "held upon trust forever." The Public Libraries Act $1850^{46}$ introduced library services alongside

42 For a list of local authority and university financially motivated disposals, see Warren (ed) The Legal Status of Museum Collections at 5.

43 For more analysis of the extent to which local authorities enjoy autonomy from central government, see Bailey and Elliott, "Taking Local Government Seriously" 436.

44 Audit Commission, The Road to Wigan Pier, 7.

45 (8\&9 Vict) CAP XLIII.

46 (13\&14 Vict) CAP LXV 
museum services and contained the same assurance that the collections would be held upon trust forever. Yet, the Public Libraries Act 1855 omitted this key phrase and provided instead that the collections would be owned by the local authority. ${ }^{47}$ The legislation which followed enabled more local authorities to establish museums if they so wished, but it was never stated again that collections were held on trust.

The Public Libraries and Museums Act 1964 provides local authorities ${ }^{48}$ with the power to maintain museums and art galleries and to transfer a museum and its collections to another local authority. ${ }^{49}$ Where a local authority has established a museum or proposes to do so, the 1964 Act also empowers local authorities to establish a fund for the purchase of items for its collections. ${ }^{50}$ If an item is subsequently sold, the proceeds of sale may be paid into the fund and used for future acquisitions. ${ }^{51}$ Unlike the legislation governing the national museums, the 1964 Act is not imperative in tone and it does not impose any duty upon local authorities to run museums. ${ }^{52}$

The Local Government Act 1972 provides local authorities with general powers which support other legislation, such as the Public Libraries and Museums Act 1964. When gifts are made to a museum, the local authority has power to accept them, and to care for them, under the powers given by section 139 of the 1972 Act. But it is section 111(1) of this Act which gives local authorities wide powers to do anything, including purchasing and disposing of property, which will help them carry out their functions. There is no legal requirement that, for example, local authorities can only dispose of some of their collections where it can be shown to be part of good heritage management.

The lack of legal restrictions on the powers of local authorities to dispose was not apparent for many years. It was not until 1960 that it became clear beyond doubt that local authorities were not charitable bodies. ${ }^{53}$ The reason why they are not charitable is that, although they have public purposes, these purposes are too wide in scope to be charitable. For example, their powers include enforcement of planning laws, which would not be a charitable activity. However, given the uncertainty in the law in earlier times, it is not surprising that some local authorities used to accept gifts on trust for charitable purposes. ${ }^{54}$ Where this is the case, the local authority is restricted in its dealings of these donations by charity law.

47 (18\&19 Vict) CAP LXX, Part XXII.

48 This does not include town, parish and community councils; a few of these do provide museums under the powers conferred by the Local Government Act 1972, sec. 137.

49 Public Library and Museums Act 1964, sec. 12(2). There is no need for the local authority to obtain the permission of the Secretary of State or, in relation to Wales, the Welsh ministers: Local Government Act 1972, sec. 208(1).

50 Public Library and Museums Act 1964, s 15, as amended by the Local Government Act 1972, sec. 208(3)(g).

51 Public Library and Museums Act 1964, Sch. 2 at para. 3.

52 Public Libraries and Museums Act 1964, sec. 12(1), as amended by the Local Government Act 1972, sec. 272(1), Sch. 30. In contrast, a local authority has a duty to provide an efficient and comprehensive library service: Public Libraries and Museums Act 1964 , sec. 7.

53 In Re Endacott, Decd. [1960] Ch. 232, C.A.

54 Re Spence's Estate, Barclays Bank Ltd v. Stockton-on-Tees Corporation [1938] Ch. 96. 
Local authorities cannot sell objects which have been transferred on loan or deal freely with objects which are subject to charitable trusts. However, apart from these considerations, local authorities have few legal restraints in relation to selling collections. Unfortunately, this fact is not necessarily understood by the public. There is scope for confusion partly because, in order to reduce costs and obtain tax benefits, a number of local authorities have established charitable trusts to manage their museums. Members of the public may well assume that the charity owns the collections but this is not usually the case: the local authorities will normally continue to own the collections and will lend them to the charitable trust. Thus the public perception may be that these museums are governed and regulated in a similar manner to national museums when in reality this is far from the case.

Local authority museums are in a particularly difficult position because of the fact that they have been forced to become commercially orientated and competitive over the last 25 years. In general, the aim of local authorities is to achieve "best value" by providing the most efficient services for the best price. ${ }^{55}$ A scrutiny in terms of "best value" will involve placing a heavy emphasis upon financial metrics; cultural value may well not be included in any assessment of a collection. Furthermore, the local authority is obliged to carry out regular 'best value' reviews: this may mean that museums are being subjected to far greater scrutiny than they were in the past. ${ }^{56}$ There is therefore an advantage in separating the management of a museum (by establishing a charitable trust to manage it) from management of other local authority services: it allows the museum to focus upon what it does best, which is engaging and educating the public. However, as the charitable trustees will be accountable to the local authority, there will still be a continuing emphasis upon value for money; this may lead not only to cutting of staff numbers, ${ }^{57}$ but may also encourage reckless sales from museum collections.

\section{SALES AND ETHICAL GUIDELINES}

\section{Curatorially motivated disposals}

The Museums Association's first Ethical Code, the Code of Practice for Museum Authorities, adopted in 1977, stated that museums should acquire objects and keep them for posterity; it introduced a strong presumption against the disposal of any objects in a collection. But it added that, in the event of a disposal, the object should be offered to other museums first and any proceeds of sale should be spent on purchasing new objects for the collections. The lack of enthusiasm for the disposals process was almost certainly based upon fear: there was serious concern that, if disposals were in any way encouraged, it could lead to a change in government attitudes, whereby financial support

55 Local Government (Best Value and Capping) Act 1999.

56 Lawley, "Local authority museums" 75, 79.

57 See the treatment of Ipswich museums: 'Good, Better, Best' (1999) August Museums Journal 43. 
would be cut in the expectation that museums could sell parts of their collections to meet their running costs.

Nevertheless, the Code of Ethics, and its predecessors, had always accepted that there might be a good reason for deaccessioning an object such as where, for example, the object was of no interest to visitors to the museum concerned. But there has always been an emphasis upon retaining the object in the public sphere. Paragraph 6.10 of the current Code of Ethics states,

"Give priority to transferring items, preferably by gift to registered or accredited museums. Consider donating items to other public institutions if it is not possible for another museum to accept them. To maintain public confidence in museums wherever possible do not transfer items out of the public domain."

In making any decision in relation to disposal, a museum would need to act in the public interest. This central tenet guiding every museum can be found in paragraph 6.1 of the Code of Ethics, which states that museums, "Act as guardians of the long-term public interest in the collections." As most objects will be transferred to other museums and will remain in the public sphere, this restriction is easily satisfied. However, the Code's general principles provide helpful guidance to a museum. Suppose, for example, that a museum offers to give an item to another museum. It is possible that more than one museum may offer a home for the object. In this situation, a museum may well choose between the museums by selecting the one which offers the most convincing evidence that there will be active public engagement with the object.

Even where a disposal was made for curatorially motivated reasons, an object might be sold and could return to the private sphere if no museum or other public body wanted the object. For example, a museum might wish to dispose of a commonplace object such as a Victorian bed warmer: if no museum wants it, it is better in terms of heritage management to save it from destruction by selling it to a private purchaser and using the proceeds to benefit the rest of the collection.

\section{Financially motivated disposals: selling to raise money}

In the wake of a controversial sale of part of a collection by Derbyshire County Council in 1991 which led to its expulsion from the Museums Association, together with threats by other local authorities to sell, ${ }^{58}$ the 1994 revision of the Code of Ethics took a firm stand, banning any disposal which was carried out as a means of raising money. However, in 2003, there was fresh scrutiny of the ethical principles relating to disposal by the National Museums Directors' Council (NMDC) in a Report entitled Too Much Stuff? The document noted that in a number of instances museums could not afford to preserve items, which had gradually fallen into decay before being destroyed. It argued that museums should much more actively consider disposing of items (whether by gift, loan or sale) in order to ensure that the items were preserved and used.

The Report also questioned whether there should be a ban on financially motivated disposal, discussing whether the British museums should be able to freely deal with objects in their collections by trading up for more interesting replacements. This practice

58 Jenkins, "Just Say No," 72; Heal, "The great giveaway," Robertson, "Infamous deaccessions," 168. 
is not uncommon in the USA, where a large number of museums are private institutions. ${ }^{59}$ Yet, there are obvious dangers in this free interchange between the public and private spheres. One risk is that governing bodies might be tempted to sell items which were out of fashion - and such items will not realise high prices. An associated risk is that, if items were sold and then these sales were viewed (with the benefit of hindsight) as a major mistake, the museum might not be able to afford to reacquire them. NMDC concluded,

"There is a place for both museums which improve and refine their collections through purposeful disposal and for those which retain the evidence of other generations' tastes and attitudes, and provide opportunity for re-evaluation and rediscovery of particular works as taste changes."60

This statement is a reminder that every museum is different and that any governing body must consider the mission of its museum and the state of its collections. Some museums cannot or should not acquire any new objects or dispose of old ones: the Wallace Collection is an obvious example. Other museums may wish to use their existing collections but to present them to the public in a fresh and more relevant manner. However, where a museum is overwhelmed with "too much stuff," some rationalisation may be sensible in the long term interest. But, of necessity, the NMDC stopped short of encouraging museums to sell on the open market to obtain the best price in order to trade up by buying a "better" item. This would be a financially motivated disposal and, at the time of the publication of this Report, this type of disposal was absolutely forbidden by the Code of Ethics.

The Report by the NMDC was followed by the Museums Association's Report, Collections for the Future, in 2005. It was suggested that museums needed to consider how to make the most of their collections and that this might well mean disposing of unwanted items. Following the publication of the Report, the Museums Association engaged in extensive consultation and received over 90 individual submissions from museums and other stakeholders regarding whether objects could be sold. The consultation revealed that attitudes had changed within the museum sector. There appeared to be agreement that sales for financial reasons to raise money would be tolerated in certain circumstances. As a result, the Code of Ethics was revised in 2007, and this revision (and the current version published in 2010) permits what is known as "financially motivated" sale but subject to severe restrictions set out in Part 6 of the Code of Ethics. The cautious approach taken is unsurprising: the sale of the object will normally be carried out by way of a public auction and it is likely to pass into private hands.

The Code of Ethics reminds museum professionals that financially motivated disposals risk "damaging public confidence in museums and the principle that collections should not normally be regarded as financially negotiable assets." Paragraph 6.13 states that museums should "Refuse to undertake disposal principally for financial reasons, except in exceptional circumstances, as defined in 6.14." The restrictions on a proposed sale are set out in paragraph 6.14, which require a museum to demonstrate that:

- It will significantly improve the long-term public benefit derived from the remaining collection;

- It is not to generate short-term revenue (for example to meet a budget deficit);

59 Fincham, "Deacccession" 99.

60 NMDC, Too much stuff? 11. 
- It is as a last resort after other sources of funding have been thoroughly explored;

- Extensive prior consultation with sector bodies has been undertaken;

- The item under consideration lies outside the museum's established core collection as defined in the collections policy.

Paragraph 6.15 adds a final touch to the list of restrictions with arguably the most important point of all: the proceeds of sale must be ring-fenced "solely and directly for the benefit of the museum's collection."

The conditions set out in paragraph 6.13 to 6.15 are not there in order to deter financially motivated sales, even if this is their effect in practice. They are an attempt to articulate how museums should act for the public benefit when considering a sale on the open market. A financially motivated sale involves high risks: the object is likely to be highly valuable, worth hundreds of thousands or millions of pounds, reflecting its immense cultural value; it may well disappear - never to be seen again - into a private collection. These ethical restrictions are intended to prevent reckless actions. But they do appear to reinforce the notion that, as a general rule, collections are to be preserved within the public domain.

\section{Further guidance on financially motivated sales}

A large number of UK museums and galleries have registered under the Accreditation Scheme, which is administered by the Arts Council of England (ACE). The Scheme sets out nationally agreed standards in relation to the management of collections. It follows the principles to be found in the Museums Association's Code of Ethics, particularly as regards serving the long term public interest by safeguarding museum collections, and respecting the interests of stakeholders. If a museum ignores the ethical principles in the Code of Ethics, it can be expelled from the Museums Association. Furthermore, if it is an accredited museum, the Arts Council may decide to remove its accreditation. Loss of accreditation is significant because the museum is then unable to apply for any of the public grants on offer from bodies such as the Heritage Lottery Fund. It may find it difficult to borrow objects from other museums and it will suffer a loss of reputation.

The consequences of a breach of the conditions set out Part 6 are therefore severe. ${ }^{61}$ Yet Part 6 was open to challenge because it was vague in parts. Even the notion of "financially motivated" had not been defined. Guidelines were therefore drawn up to flesh out Part 6 by the author together with representatives from the Museums Association and Arts Council England. ${ }^{62}$ Members of the museum sector and the Ethics Committee, along with regional bodies such as Museums Galleries Scotland, Museums Archives and

61 The guidelines in Appendix 4 of the Disposal Toolkit state that the museum will usually be excluded from the Accreditation Scheme for a period of five years. See further, the Joint Statement - Unethical Sale from Museum Collections, available at http://www. museumsassociation.org/download?id=1141616.

${ }^{62}$ The author is particularly grateful to Maurice Davies and Sally Colvin from the Museums Association, and Isabel Wilson and Samuel Rowlands from Arts Council England. 
Libraries Wales and the Northern Ireland Museums Council, assisted with advice. The guidelines can now be found in Appendix 4 of the revised Disposal Toolkit. ${ }^{63}$

The definition of "financially motivated" was problematic because a survey of past disposals revealed that there was a rather hazy borderline with curatorially motivated disposals. For example, in 2008, the Watts Gallery auctioned off two paintings, the proceeds of which were used to benefit the remaining collection. Although this was presented as a curatorially motivated disposal (as the Gallery had attempted to find a museum which would buy them), it could more readily have been interpreted as a financially motivated disposal. ${ }^{64}$ The definition which was finally agreed can be found in the Glossary of the Disposal Toolkit. It is stated that a financially motivated disposal is one where,

"a primary reason for disposal is to raise funds."

It was thought best to avoid defining a "financially motivated" sale too narrowly. Members of a governing body of a museum might have a number of different reasons for deciding upon a sale on the open market. They could argue that they were engaged in a curatorially motivated sale because obtaining money was not "the" primary reason. The effect of having a flexible definition, whereby the objective of raising money merely has to be one objective but not necessarily the main objective, is that far more sales will be subject to scrutiny to ensure that they comply with paragraphs 6.13 to 6.15 . Widening the net in this way is desirable because these ethical conditions are intended to ensure that museums do not commodify objects but act as stewards of their collections for current members of the public and future generations.

The guidelines in Appendix 4 of the Disposal Toolkit set out a procedure for museums to follow, which consists of a series of stages. At the first stage, the guidelines require a report to be drawn up for submission to the governing body, forcing staff to gather together a large amount of factual information. For example, paragraph 1.4 .2 requires the report to the governing body to include statements regarding:

- how the particular items chosen for sale were selected; and

- why other items were not selected instead.

For example, a decision to sell high value items relative to the collection as a whole may require a more detailed explanation of how this decision was arrived at in order to demonstrate that items are not being selected for sale solely on the grounds of their financial value.

The level of detail was thought necessary because, if a financially motivated sale is contemplated, the governing body will be expected to contact the Museums Association and the Arts Council at this first stage. It is important that these bodies should be supplied with sufficient information to enable them to respond in an effective manner.

One problem, in drawing up these guidelines, was to determine a structure. In particular, museums might wish to consult others either at an early stage or much later in the process. The guidelines therefore recognise the possibility that there may be consultation at the first stage ${ }^{65}$ whilst demanding that by the end of the third stage, extensive consultation should have occurred. Museums are expected to engage in risk

63 "Additional Guidance on Financially Motivated Disposal" available at http://www.artscouncil.org.uk/media/uploads/pdf/Disposal_Toolkit_Appendix_4.pdf

64 For critical discussion, see D. Rykner, The Art Tribune (2008) $\overline{1}$ March.

65 See Appendix 4 of the Disposal Toolkit at paras. 1.4.2 and 1.5. 
management, making more enquiries and carrying out more consultation where there are problems with the provenance of an object and there is a possibility that it may have been smuggled into this country, or may be a forgery, or may be far more valuable than appreciated. ${ }^{66}$ However, some flexibility is built into the consultation process. For example, paragraph 3.1.6 suggests consulting people and publicising the proposed sale in a manner which is "appropriate in the circumstances." This gives museums the opportunity to use their discretion and if, for example, they prefer to consult via the internet in order to avoid security issues, this would still comply with the guidelines.

The guidelines provide a series of stages with a view to creating periods of reflection. There is no possibility of a rushed sale if the process set out is followed properly. It should mean that governing bodies can confidently say that they have taken great care in disposing of a valuable object.

\section{COMMERCIAL LAW AND COLLECTIONS}

\section{Sale and leaseback agreements?}

One question which I was asked in preparing the guidelines on financially motivated sales was whether a museum could avoid an outright sale and sell the object instead to a private purchaser on condition that the purchaser lent the object back to the museum for a certain period of time (such as two months) each year. The thinking behind this question was that the museum could raise money in this manner but the object would not be lost permanently to the viewing public.

Sale and leaseback arrangements are commonly used in business to raise funds. The seller will make use of this arrangement in order to continue in possession of the object whilst obtaining an immediate injection of cash. ${ }^{67}$ However, if a work of art or antiquity was put up for sale, there is a risk that a condition whereby the object must be returned to the museum each year for a period of time would depress the price which it would otherwise realise. The art market is international in character. Many prospective purchasers are resident abroad and would not be prepared to commit to shipping the artefact to the UK for a period of time each year. The object would be at risk of being damaged or stolen whilst it was in transit and it is not clear who would bear the costs of insurance. Furthermore, the objective of retaining the object in the public sphere for part of the year could not be guaranteed. If the purchaser resold without imposing these conditions on a sub-purchaser, a museum might not have the resources to sue the purchaser for breach of contract. Another possibility is that the purchaser might die. There is no obvious legal basis which would allow the museum to enforce this arrangement against the person entitled to the object after the death of the purchaser.

66 See Appendix 4 of the Disposal Toolkit at para. 2.1.3.

67 The lease is normally for a period of years. For a discussion of certain risks inherent in these arrangements, see Ulph, "Sale and Leaseback." 
However, a more important objection is that, if a sale and leaseback was arranged, there might be a breach of ethical principles. If a museum wanted to take the object on loan for several months each year, then it is evident that it is being engaged with by the public and that it is not a suitable object to be disposed of in the first place.

\section{Co-ownership?}

Another option for raising money would be to sell a share of the object so that there would be co-ownership between a museum and a private company or private collector. This stratagem would enable the museum to raise money but it would avoid the risk of losing the object entirely to a private collection. Yet it can be argued that this type of arrangement is also fraught with difficulty in the context of the museum sector. There is a risk that the co-owner might be later revealed as an ethically dubious character. For example, suppose the co-owner was a collector who was subsequently convicted of a criminal charge involving stolen antiquities? This arrangement could cause great reputational damage to a museum.

Furthermore, the law relating to co-ownership of moveable objects still remains in a somewhat undeveloped state. Although the common law and, more recently, statute law recognise arrangements to co-own moveable property in the commercial sphere, coownership is not common outside a few established categories, such as co-ownership of racehorses. ${ }^{68}$ In contrast, arrangements to lend any type of moveable object have been made on a daily basis day for centuries. Loans by museums to other museums are also quite common and serve the public interest by increasing public engagement with heritage objects. A short term loan to a private body is surely a better way to raise money whilst, from an ethical perspective, it can be said to provide an opportunity for the object to be engaged with in a different setting.

\section{Selling at less than the market value?}

Until recently, it had been assumed that, where a museum decides to sell, it must seek the best price at public auction. This is a principle of commercial law: a trustee or agent is obliged to seek the best price in relation to a sale, unless the contract provides otherwise. ${ }^{69}$ However, standard commercial law principles, which work well in a situation where the only purpose is a financial one, should not be automatically applied to entities which have a public purpose. Many museums are charities, with the aim of educating the public or advancing science or arts. Even private museums will have a public element as part of their mission. It can be argued that the public purpose of museums needed to be taken into account. ${ }^{70}$ There are further public benefit considerations which will affect the duties of the governing bodies. For example, they must maintain the reputation of the museum to ensure that further donations are made and that the public continue to visit

68 See Ulph "The Sale of Goods (Amendment) Act."

69 See, for example, Keppel v. Wheeler [1927] 1 K.B. 577, C.A. (estate agent).

70 In the context of administrative duties to take care in making investments, see Harries v. Church Commissioners [1992] 1 W.L.R. 1241, in which the court accepted that trustees are entitled to take account of the charitable objects of a trust. 
and engage with the collection. This may mean that it can benefit the museum to attempt to keep the items earmarked for disposal within the public domain.

Where a museum is prepared to sell for less than the estimated value in order to ensure that the object remains in the public sphere, it should be able to do so in appropriate circumstances. The Charity Commission was consulted about this issue and paragraph 2.3.3. of Appendix 4 of the revised Disposal Toolkit, which was published in March 2014, reflects that discussion. It states:

The governing body of a museum contemplating a sale at less than the market price should ensure:

- that this course of action can be justified as in furtherance of the museum's own purposes and that it is in the museum's best interests;

- that the members of the governing body are satisfied that it will remain in the public domain and will be accessible to the public; and

- that any restrictions which may have been placed on the item when it was originally donated continue once the sale has been completed, or any restrictions the selling charity put on the use of the item are met.

A lack of legal guidance in the past has severely hindered effective cultural heritage management. The law tends to be shaped by decided cases brought by commercial concerns. The guidance in Appendix 4 of the Toolkit should help museums. Even so, a museum might still feel unconfident at the prospect of selling to another museum at a significant discount because it may be problematic to assign a financial value to the museum's interests and the public benefit element. This uncertainty would cause particular concern where the object was valuable; in this situation, the trustees of a charity are still likely to seek authorisation from the Charity Commission. ${ }^{71}$

Commercial law principles do not always work well when applied in the public sphere. The Law Commission has recently considered reforming the powers of investment by trustees of public bodies. The focus of the existing law has been upon making the most money, even if it meant behaving unethically. ${ }^{72}$ But public bodies are likely to baulk at acting unethically for various reasons, not least the reputational risk. The Law Commission concluded that trustees of a public body should not focus upon financial considerations alone because they might then make investments which were hostile to the interests of their institution. It was thought that trustees of public bodies needed guidance which was much more tailored to their particular circumstances. New legislation has been recommended as a consequence. ${ }^{73}$ It is important to recognise that not all private law principles work well in the public sphere because there are other matters which need to be taken into account.

\section{Selling at less than the market value and the position of local authority museums}

71 In 1962, the Royal Academy of Arts wished to sell its Leonardo Da Vinci cartoon to raise money. The Charity Commission gave its permission for the sale (under the statutory predecessor to section 105 of the Charities Act 2011) at less than market price in order to keep this important work of art within the public domain. $£ 800,000$ was raised by public appeal and the cartoon joined the collections in the National Gallery.

72 Buttle v. Saunders [1950] 2 All E.R. 193. See Law Commission, Fiduciary Duties, Chapter 10.

${ }^{73}$ Law Commission, Social Investment by Charities. 
Local authorities are generally expected to seek the best financial return in order to serve their local community properly. ${ }^{74}$ Scrutiny in terms of "best value" would suggest that local authorities must always seek the best price. However, in other policies affecting local authorities, it has been recognised that financial value is not the only consideration where heritage assets are involved. In the context of the disposal of historic buildings, monuments, memorials, archaeological remains, historic gardens, battlefields and wrecks, guidance issued by the Department of Culture, Media and Sport has stated:

"It is government policy that the maximisation of receipts should not be the overriding objective in the disposal of heritage assets. The aim should be to obtain the best value for the taxpayer ..."75

Furthermore, the most recent raft of legislation and informal guidance presses local authorities to work to improve the social, economic and environmental well-being of local communities. ${ }^{76}$ More specifically, local authorities have been encouraged to consider transferring land and buildings at less than market value to community and voluntary sector groups in order to further these purposes. ${ }^{77}$ Under such a "community asset transfer" scheme, a local authority should inform local communities of any proposed sale and should give the communities time to put forward a bid. This legislation is relevant to the museum sector: Torridge District Council transferred the collections of the North Devon Maritime Museum, together with the building in which they were housed, to an independent trust under this scheme. Paragraph 2.3.3 of Appendix 4 of the revised Disposal Toolkit therefore states:

Local authority museums may consider transfers at less than market value to other museums. For example, a substantial discount in the market value can be offered when land and buildings, as well as the museum collection, are being transferred under a community asset transfer to further local, social, economic and environmental wellbeing, in accordance with the Localism Act $2011 .{ }^{78}$

However, it is far less clear whether local authorities are expected to seek the best owner rather than the best price where the heritage assets are moveable property, such as museum collections. In any event, the "best price" can be a matter of guesswork in relation to works of art and antiquities. The only way of determining an approximate price is to consider the price which similar objects have realised at auction; yet cultural objects are often unique and their price will be uncertain unless and until they are sold in the open market. It may therefore be impossible to say whether an object is being sold at less than its true worth. Even so, I would suggest that there is an argument to be made that local authorities are entitled to sell at less than the best price envisaged where the

74 Local Government Act 1999, sec. 3.

75 Holborow, Disposal, para. 9.1.

76 Local Government Act 2000, sec. 2. See further the Public Services (Social Value) Act 2012, sec. 1(3),

77 See the Localism Act 2011; Circular 06/03: Local Government Act 1972 General Disposal Consent (England) 2003, disposal of land for less than the best consideration that can reasonably be obtained; The Disposal of Heritage Assets: Guidance note for government departments and non-departmental public bodies at http://www.englishheritage.org.uk/publications/disposal-heritage-assets/guidance-disposals-final-jun-10.pdf 78 Available at http://www.artscouncil.org.uk/media/uploads/pdf/Disposal_Toolkit_Appendix_4.pdf 
sale can be seen as improving the social, economic and environmental well-being of a local community. Paragraph 2.3.3. of Appendix 4 therefore adds:

There may also be circumstances where a sale to another museum or organisation in the public domain at less than the market value may be advisable by taking account of the need to improve the quality of services for the benefit of the public and local communities.

Local authority museums will need to consider whether the disposal of any item adversely impacts upon those groups with protected characteristics under the Equality Act $2010 .{ }^{79}$ Retention of the item in the public domain could mitigate any adverse impact.

Local authorities are subjected to many different demands. Different laws, each with their own rationale, point in different directions. No thought appears to have been given to overall heritage management. This lack of joined up thinking makes the application of the law obscure in relation to free transfers and sales from museum collections.

\section{Commercial Thinking and Local Authority Museums}

As a consequence of modern structures of governance, it is likely to be councillors rather than curators or museum directors who will be the decision makers in relation to disposals from museum collections owned by local authorities. For example, some local authorities have adopted a Cabinet system, whereby decision making powers for particular sectors (such as leisure or business) are devolved upon particular councillors. ${ }^{80}$ The museum is merely one of a number of services which this member will need to consider. Even where the local authority has created a charitable trust to manage the museum, as the local authority will invariably own most or all of the objects in the collections, it will remain as the ultimate decision maker. The status of museum staff has often been lowered as a result of these changes in governance. ${ }^{81}$ Thus, although at museum level, there is little danger of museum professionals viewing their collections as commercial objects, there is a risk that some members of the council, with little interest or understanding of the cultural value of certain objects in the collections, may do so.

Commercial thinking has permeated local authorities due to legislation which forces local authorities to continuously strive for "best value" by providing the most efficient and effective services for the best price. ${ }^{82}$ As local authorities are obliged to carry out regular "best value" reviews, their public characteristics are inevitably eroded by auditors and financial considerations. Legislation with a commercial orientation which is aimed at the local authority's provision of services to the locality, such as housing and environmental health, has been stretched to also cover the running of local authority museums. ${ }^{83}$

79 Equality Act 2010, sec. 4. These protected characteristics include: age, disability, gender reassignment, marriage and civil partnership, pregnancy and maternity, race, religion or belief, sex and sexual orientation.

80 Egeria and Farrer, Moving to Museum Trust, 23.

81 Kawashima, Museum Management, 20.

82 Local Government Act 1999, sec. 3.

83 For the suggestion that museum services should aim to adhere to the philosophy of Best Value: see Egeria and Farrer, Moving to Museum Trusts 4, 28. 
Some commercialisation is inevitable for all museums. The cost of preserving and protecting hundreds or thousands of objects, and maintaining the buildings in which these collections are housed, must be met. All museums must remain sustainable by marketing themselves to attract the viewing public. But in the current difficult financial climate, a large number of museums are under stress. As their income dwindles, some museums are being kept open with reduced hours, whilst others are forced into permanent closure. Local authority museum collections are especially vulnerable. Local authorities are not under a duty to run museums or to retain collections. There are no statutory provisions setting out the purposes which local authority museums are expected to achieve. In 1991, the Audit Commission observed that local authority museum collections have "tended to evolve in a piecemeal way, often without clear objectives." ${ }^{84}$ The Commission consequently recommended that museums should have a clearly stated acquisitions policy and should dispose of objects which did not fit within that policy. ${ }^{85}$ This is not a controversial statement in itself because the Commission moved on to emphasise the value of staff training, the care required in rationalising collections, and the importance of avoiding "asset stripping." ${ }^{86}$ But such details can be ignored by councillors when there are severe budgetary problems. History has taught us that financial pressures can encourage rash disposals. ${ }^{87}$ It is easy to understand why a councillor in a local authority may think it is better to sell an object by auction rather than to transfer it to another museum as a gift; the money raised by a sale could be used to keep the museum going or to spend on other social projects.

It can be argued that councillors who see collections as commercial assets which should be used to generate large sums of money display a wilful degree of ignorance. Policy objections to selling off collections include, apart from betraying the trust of generations of donors, the fact that it is an easy way to conceal any economic mismanagement or incompetence. It is unsound from a business perspective. Irresponsible sales from collections will deter public giving, staunching the flow of generosity. Staff morale is damaged and, as the Culture Media and Sport Committee observed, "Museums cannot perform adequately if they exist in a climate of threat to the collections and to the staff." ${ }^{88}$ There is the fear that, if such sales were common and accepted, it might lead people to assume that all the costs associated with running a museum could be paid for by selling something. There are ethical objections as well. The Culture Media and Sport Committee stated that, "We believe that there is a moral duty on councils to hold cultural collections in trust for the wider community." 89 This comment is supported by recent legislation and informal guidance which, as mentioned above, has directed local authorities to work to improve the social, economic and environmental well-being of local communities. ${ }^{90}$

\footnotetext{
84 Audit Commission. The Road to Wigan Pier, 7.

85 Audit Commission. The Road to Wigan Pier, 6-7.

86 Audit Commission. The Road to Wigan Pier, 7.

87 For a discussion of some of the misconceived sales by German and Austrian

museums in the 1950s, see the Editorial, "The Sale of Works" 3.

88 House of Commons, Caring for our Collections, at para. 8.

89 House of Commons, Caring for our Collections, at para. 23.

90 Local Government Act 2000, sec. 2; Local Government Act 1972 General Disposal

Consent (England) 2003; Localism Act 2011; Circular 06/03; Public Services (Social

Value) Act 2012, sec. 1(3).
} 
The sale of the Sekhemka statue by Northampton Borough Council (NBC) for almost $£ 16$ million in 2014 is a recent example of a financially motivated sale which did not comply with the Code of Ethics. NBC commissioned a valuation of its collections in 2010 and, upon discovering the high value of the statue, promptly began to plan to sell it to raise money. These discussions took place long before the detailed guidance in Appendix 4 of the Disposal Toolkit had been published. Even so, it was clear that the process of disposal did not satisfy the requirements of Part 6: this sale was not a last resort and there had been no proper consultation with stakeholders. The obvious and serious risk of eroding public trust and deterring public giving was only one of many reasons for criticising this sale.

NBC's museums had their accreditation removed by Arts Council England for a minimum period of five years after the sale took place in 2014. This action will have an impact upon staff morale. It will mean that there is no possibility of applying for funding from bodies such as the Art Fund. Moreover, the Northampton community is now deprived in a permanent way of the opportunity to view the Sekhemka statue. It had great international importance and would have been interesting to both scholars and the ordinary visitor if presented properly. ${ }^{91}$ Yet the community did not have the benefit of its full sale value instead. It had been agreed by NBC that Lord Northampton would receive $45 \%$ of the net proceeds of sale. There had been some doubt over the circumstances surrounding the acquisition of the statue by NBC. It appeared to have been one of a number of objects transferred by the third Marquis of Northampton in 1880 by way of a Deed of Gift. However, this Deed stipulated that all of the property transferred by the Deed must be exhibited to the public; it went on to provide that, if the local authority failed to do this, the third Marquis, or his heirs, could retake possession of such property. There was therefore an argument (however weak) for saying that the statue had merely been transferred on loan from the Northampton family and that NBC was not entitled to sell it. Lord Northampton agreed to accept a portion of the sale price in settlement of his claim. The Northampton community therefore lost the statue but did not obtain the benefit of the full sale price. At the time of writing, the purchaser of the statue itself is unknown.

A further reason for condemning this type of ill-considered sale is that it can diminish the standing of the United Kingdom. The proposed sale of Sekhemka prompted protests from the Egyptian Ministry of Antiquities and Heritage which condemned the sale. Accordingly to Al-Ahram Weekly, Minister Mamdouh Al-Damati stated that

"the museum's decision is 'incompatible' with the values and role of museums worldwide, which he said should 'spread culture' and not try to earn money."

Another objection is the sheer waste of resources as various public bodies became involved in scrutinising NBC's conduct, such as the Museums Association, the Arts Council and the International Committee for Egyptology in the International Council of Museums. A final concern is that the sale of the statue might well encourage theft and smuggling of Egyptian antiquities to international markets: the high price commanded by the statue is expected to fuel demand by private collectors. ${ }^{93}$ Yet it is not a function of local authorities to trade in art and antiquities: their functions are concerned with serving the inhabitants of their local area. The sale of the Sekhemka statue demonstrates how

91 See James, "The Northampton Statue."

92 Al-Ahram Weekly Issue 1205, 10 July 2014.

93 See generally Ulph and Smith, The Illicit Trade. 
important ethical guidance is, in the absence of law, in directing all museums to preserve public trust and to work for the public benefit.

But if the sale of the Sekhemka statue appears to demonstrate a complete failure of the law, what should be done? Should the law be reformed to prohibit financially motivated disposals so that no object in a collection is ever transferred to the private sphere? I would suggest not. In 2007, there was a consensus amongst museum professionals that there might be circumstances in which a financially motivated disposal, which was responsibly carried out, would be acceptable. A complete ban on such sales would be too rigid and would not be desired. Furthermore, local authorities could respond to a ban on all such sales by closing down a museum and selling all the assets. Consequently, any law banning financially motivated sales might not work unless it also imposed a duty upon local authorities to run existing museums.

It would be difficult to reform the law in a more limited way by preventing local authorities from selling objects with a "high" cultural value at auction. It is very difficult to define heritage objects in law. To date laws affecting the UK have normally arrived at a compromise, which takes criteria linked to age and financial value into account. ${ }^{94}$ It would be impracticable to create a law which says that there are some heritage objects which cannot be sold because it would be impossible to define the borderlines.

There is a need for law reform. In the Cottesloe Report, it was suggested that works of art and collections in the possession of local authorities "are already public possessions and if they are of national importance they should remain in this country and accessible to the public." 95 The Report therefore recommended that the government should announce that it would not grant an export licence to works of national importance from local authority collections. ${ }^{96}$ This recommendation was not acted upon. However, it does have the merit of discouraging sales: If the work cannot be exported, the local authority would not be able to obtain a high price for it. On the other hand, it might not be easy to administer: a local authority could sell an object to a private individual in the UK who might resell it to an international buyer many years later: the export ban may be difficult to enforce in these circumstances.

I would suggest that law reform could take the form of a statutory provision which declared that local authorities held their collections in trust for the public, and that any disposal must be in the public interest, and that any proceeds of sale must be spent upon conserving the remaining objects in the museum collections (with a direction that, if this is not possible, the money should be paid into a charitable fund to assist charitable museums). This declaration would not hinder any disposal but a local authority would not be able to spend the money to satisfy another statutory function, be it road maintenance or social services.

\section{CONCLUSIONS}

\footnotetext{
94 See for example the Annex to Regulation 116/2009.

95 Report into the Sale of Works of Art by Public Bodies, at para. 87.

96 Ibid, para 100 (iii).
} 
Museums attempt to reach out to inspire the widest possible audience and their collections will usually be central to that dialogue with the public. Yet he legal regulation of museum collections has received insufficient attention in the past. This is regrettable because works of art, antiquities and other objects can have a deep meaning not only to local communities but also to researchers and the whole of mankind.

The law governing the disposal of museum collections should reflect this cultural dimension. This article has argued that great caution is needed in drawing upon principles which have been developed in the context of private companies and trusts which are concerned purely with making profits. Commercial thinking will not provide a complete answer and more attention needs to be given to how legal principles should apply to a public body acting for the public benefit. In particular, this article has sought to demonstrate that new legislation is needed which would clarify the law relating to the collections of local authority museums. It is suggested that they must hold their collections in trust for the public. This reform would remove uncertainty, comply with ethical guidance, save costs for other public bodies and maintain the high reputation of museums amongst the public both in this country and overseas. Most importantly, it would mean that the law mirrored public expectations. It is all too easy for someone to be misled by the fact that a local authority museum is managed by a charity and to donate an object on the assumption that the object will belong to the public forever when in fact it is vulnerable to being sold at the whim of the local authority some years later.

The current position is that the vacuum in the law relating to disposals has been filled by ethical principles. If the law was reformed, they would continue to play a vital role. The Code of Ethics has fleshed out what holding collections "in trust" actually entails in practice. It has been instrumental in helping museums to maintain public trust, whilst other public institutions have not been so fortunate. ${ }^{97}$ It has done so by emphasising the need for transparent procedures of disposal, consulting a diverse range of stakeholders, and considering the interests of different generations.

Both law and ethics must strike a balance between competing policy concerns. Museums should be encouraged to review their collections, to learn more about them and to give, lend or sell unwanted items. This process is time-consuming but benefits everyone if it is done thoughtfully and well. But reckless selling for financial gain needs to be prevented. A donor may have transferred works of art in the past in the expectation that they would be enjoyed by the public forever; in order to preserve pubic confidence, these works should not be sold to disappear from public sight forever whilst the proceeds of sale are frittered away.

\section{BIBLIOGRAPHY}

${ }^{97}$ See Britain Thinks: research found that people have a strong emotional attachment to museums and that museums hold a unique position of being trusted. 
Audit Commission Local Government Report. 1991. The Road to Wigan Pier Managing Local Authority Museums and Art Galleries. No 3 London, HMSO, 7. see Bailey, Stephen and Elliott Mark, 2009. "Taking Local Government Seriously: Democracy, Autonomy and the Constitution" 68(2) Cambridge Law Journal 436. Britain Thinks: Public perceptions of - and attitudes to - the purposes of museums in society. 2013. Museums Association Report.

Cottesloe Report. 1964. The Report of the Committee of Enquiry into the Sale of Works of Public Bodies.

Disposal Toolkit and Additional Guidance on Financially Motivated Disposal (Museums Association, 2014) available at:

http://www.museumsassociation.org/collections/disposal-toolkit

Editorial, "The Sale of Works Out of Museums" 1960. 102, no. 682, The Burlington Magazine 3.

Egeria and Farrer and Co. 2006. Moving to Museum Trusts. Museums Libraries and Archives Council. Available at www.egeria.org.uk/index.php/download_file/view/12/73/ Fincham, Derek. 2011. "Deacccession of Art from the Public Trust" XVI Art Antiquity and Law 93.

Heal, Sharon. 2006. "The great giveaway," Museums Journal 106/10, October, 32. Holborow, Will. 2008. The Disposal of Heritage Assets. DCMS.

House of Commons, Culture Media and Sport Committee, Caring for our Collections, Sixth Report of Session 2006-07, Vol 1.

James, TGH. 1963. "The Northampton Statue of Sekhemka" 49 The Journal of Egyptian Archaeology 5.

Jenkins, Tiffany. "Just Say No: You Cannot Be Too Careful in Embracing Disposal." 2011. Davies, Peter (ed). Museums and the Disposal Debate. Edinburgh, MuseumsEtc Publishing, 72.

Kawashima, Nobuko. 1997. Museum Management in a Time of Change: impacts of cultural policy on museums in Britain 1979-1997. (Working Paper, Centre for the Study of Cultural Policy, Warwick: University of Warwick.

Law Commission Consultation Paper No 215, 2013. Fiduciary Duties of Investment Intermediaries.

Law Commission Consultation Paper No 216, 2014.Social Investment by Charities. Lawley lan. 2003. "Local authority museums and the modernizing government agenda in England," 1 (2) Museum and Society 75.

Mahon, Denis. 1988. "Disposing of Disposal," Editorial, 130, No. 1027, The Burlington Magazine, 731.

"Museums and Art Galleries Report" R10 (Version 08/02). Charity Commission. Available at: http://www.charitycommission.gov.uk/media/95113/rr10text.pdf National Museums Directors' Council (NMDC). 2003. Too much stuff? Disposal from Museums, available at

http://www.nationalmuseums.org.uk/media/documents/publications/too_much_stuff.pdf.

Robertson Ian. 1995. "Infamous deaccessions," in Fahy, Anne, (ed) Collections Management. Routledge, 168.

Saumarez Smith, Charles. 1989. "Museums, Artefacts and Meanings" in P Vergo (ed) New Museology, 6.

Ulph, Janet. 1996. "The Sale of Goods (Amendment) Act", Co-ownership and the Rogue Seller." Lloyd's Maritime and Commercial Law Quarterly 93-107.

--- 2001. "Sale and Leaseback Agreements in a World of Title Relativity" 64 Modern Law Review 481.

Ulph, Janet, and Smith, Ian. 2012. The Illicit Trade In Cultural Property: Money

Laundering, Criminal and Civil Liability, and Recovery. Hart: Oxford. 
Warren, Jeremy (ed). 1996. The Legal Status of Museum Collections in the United Kingdom. Museums and Galleries Commission. 